\title{
Oral Mukozanın Malign Hastalıkları
} Malignant Diseases of the Oral Mucosa

\section{Burhan Engin, Orkhan Bairamov, Zekayi Kutlubay, Yalçın Tüzün}

İstanbul Üniversitesi Cerrahpașa Tıp Fakültesi, Deri ve Zührevi Hastalıklar Anabilim Dalı, İstanbul, Türkiye

\section{Özet}

Dünyada önemli bir sağlık sorunu olan oral kanser, baș ve boyun kanserlerinin bir alt tipidir. Bu kanserler dünya çapında 6 . en sık rastlanan malign tümörlerdir. Ağızdaki tüm malign tümörlerin \% 90'ı skuamöz hücreli karsinomdur. Oral skuamöz hücreli karsinomun etyolojisi karmașıktır. Özellikle gelișmiș ülkelerde en önemli risk faktörleri, sigara ve alkol alımıdır. (Türkderm 2012; 46 Özel Sayı 2: 90-5)

Anahtar Kelimeler: Oral mukoza, oral kanser, skuamöz hücreli karsinom

\section{Summary}

Oral cancer which is a significant world health problem is a subtype of head and neck cancer. They are the sixth most common malignant tumors worldwide. More than $90 \%$ of malignant tumors in the mouth are squamous cell carcinomas. Etiology of the oral squamous cell carcinoma is complex. The most important risk factors, especially in well-developed countries are tobacco smoking and alcohol exposure.. (Turkderm 2012; 46 Suppl 2: 90-5)

Key Words: Oral mucosa, oral cancer, squamous cell carcinoma

\section{Giriș}

Oral mukozada gelişen malignitelerin \%90'dan fazlasının skuamöz hücreli karsinom (SHK) olduğu belirtilmiştir. Bunun \%30'a yakını dudakları etkiler. Ağız içi ve dildeki yerleşim, temas edilen maddelere göre değişiklik gösterir. Ağız içi kanserlerinin çoğunluğu ağız tabanına yerleşse de, yanak mukoza yerleşimi de temasa bağlı olarak sıklıkla bildirilmiştir.

\section{Skuamöz Hücreli Karsinom}

\section{Sıklık}

Oral malignite gelişiminin Hindistan, Fransa, Güney Afrika, Brezilya ve Avustralya gibi ülkelerde sıklıkla arttığı bildirilmiştir ${ }^{1}$. Ülkemizde oral malignite sıklığı ile ilgili bir veri bulunmamakla beraber, dudak mukozası da düşünüldüğünde görülme sıklığının artmakta olduğu söylenebilir. Birinci derece akrabalarında oral SHK görülen kişilerde SHK gelişme sıklığı artmaktadır.

\section{Etyopatogenez}

Hastalık etyopatogenezinde ultraviyole radyasyonu (genelde alt dudağı etkiler), sigara, tütün, "betel" (benzopren, nitrozamin) çiğnenmesi, ayrıca oral HPV infeksiyonu, kronik alkol tüketimi, meyve ve sebzelerden fakir diyet, ağız içi hijyen bozukluğu ve diş protezleri risk faktörleridir ${ }^{1}$.

Lökoplaki ve eritroplaki gibi oral mukozaya yerleşen bazı premalign hastalıkların SHK gelişme riskini arttırdığı bilinmektedir1,2. Bunların dışında oral liken planus, diskoid lupus eritematozus ve submukozal fibrozis riski arttıran hastalıklardır. Farklı çalışmalarda, immün süpresif hastalarda oral SHK sıklığının özellikle gençlerde arttığı gözlenmiştir. Lökoplaki, oral mukozanın en sık rastlanan premalign lezyonu olup, 50 yaş üstü erkeklerde daha sık rastlanır1,3. Eritroplaki, lökoplakiden daha az sıklıkta görülmesine rağmen malignite gelişme riski daha fazladır. Oral liken planusun genelde erozif ve ülseratif tiplerinde malign dönüşüm görülebilir (Resim 1). Bu hastalarda oral hïyen bozukluğu, dental işlemler, gıdalar ve sigara kullanımı gibi

Yazışma Adresi/Address for Correspondence: Dr. Burhan Engin, Istanbul Üniversitesi Cerrahpașa Tıp Fakültesi, Deri ve Zührevi Hastalıklar Anabilim Dalı, Istanbul, Türkiye Tel: +90 2124143119 E-posta: bengin@istanbul.edu.tr

Türkderm-Deri Hastalıkları ve Frengi Arșivi Dergisi, Galenos Yayınevi tarafindan basılmıștır.

Turkderm-Archives of the Turkish Dermatology and Venerology, published by Galenos Publishing. 
faktörler bunu daha da kolaylaştııılar. Diskoid lupus eritematozus lezyonlarında oral malignitelere nadir de olsa rastlanır ve genelde alt dudak etkilenir (Resim 2). Submukozal fibrozis ağız içi mukozada sarımsıbeyaz renk değişimi şeklinde kendini gösterir. Sıklıkla tütün çiğneme alışkanlığının olduğu Asya'da görülür2-4.

Oral mukozaya yerleşen HPV'nün kadınlarda serviks kanseri gelişimindeki gibi oral karsinogenezde de rol oynadığı bazı çalışmalarda gösterilmiştir.

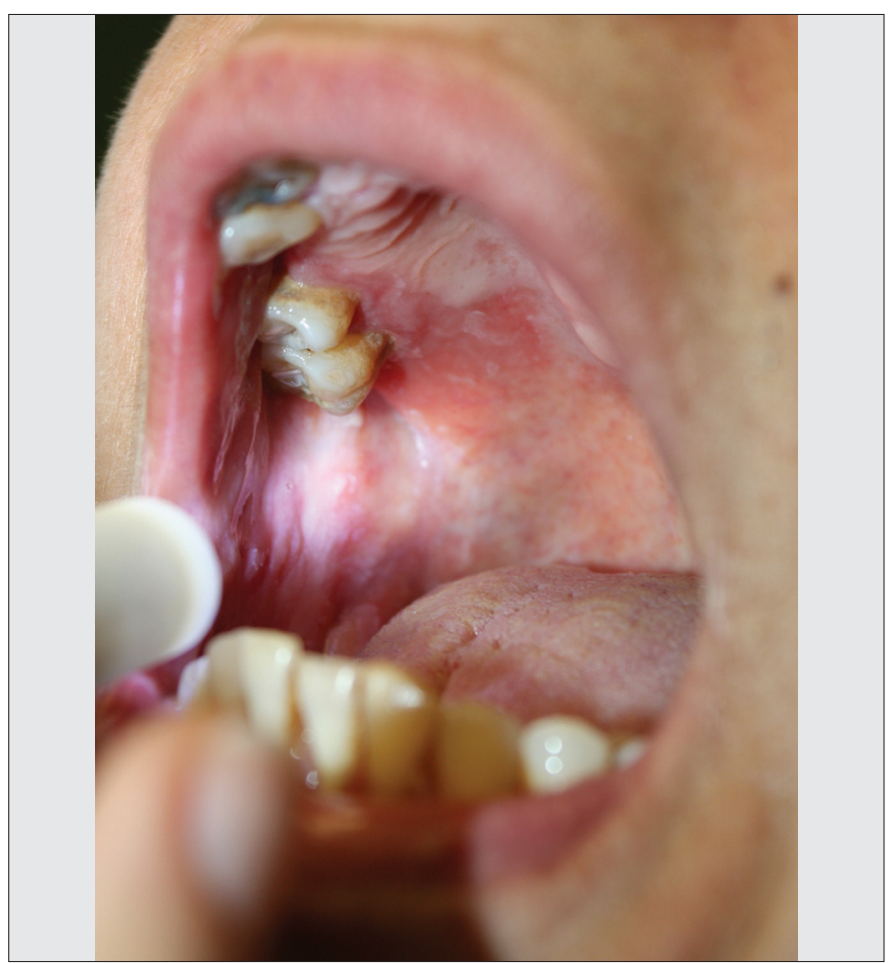

Resim 1. Uzun süreli oral liken planusu olan hastada gelişen karsinom

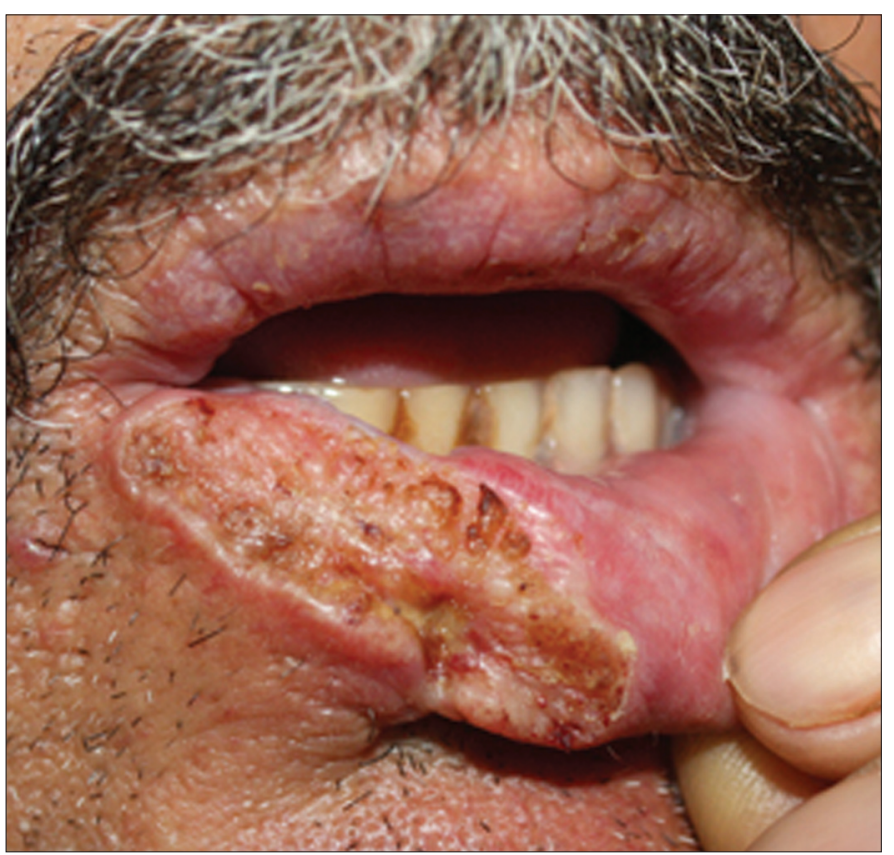

Resim 2. Alt dudakta diskoid lupus eritematozus sonrası gelişen skuamöz hücreli karsinom
Oral karsinogenezde HPV 16 ve 18 tipleri suçlanmıştır. Bunlardan HPV 16 'ya daha sık rastlanır ve oral SHK görülme sıklığını 6-7 kez artııır5.

\section{Klinik Özellikler}

Muayenede farklı klinik özellikler tespit edilebilir. Yüzeyi fissürlü veya ülsere, kenarları kabarık bazen anormal vaskülarizasyonlu sert infiltre tümör tipiktir (Resim 3). Hastalarda şikayet olarak ağrı, disfaji ve kilo kaybı bulunabilir. Ağız içerisinde yerleşen SHK olgularında mutlaka değerlendirilmesi gereken boyun yerleşimli büyümüş lenf nodlarına; infeksiyon veya metastatik hastalık neden olabilir. Bazı olgularda tümöre ikincil gelişen reaktif hiperplazi söz konusudur1,6.

Oral mukozaya yerleşim gösteren klasik SHK; değişken dereceli keratinizasyon, pleomorfizm ve mitotik aktivite ile karakterizedir. Tümörün büyüklüğü, lokalizasyonu, histolojik malign tabakası, perinöral yayılımı, lenfovasküler invazyonu ve kalınlığı prognozu etkileyen önemli faktörlerdir¹.

Ackerman tümörü olarak da bilinen verrüköz karsinom oral SHK'nin iyi diferansiye tipi olarak sınıflandırılır. Genelde yanak mukozasında ve sert damakta yerleşen tümör klinik olarak ekzofitik ve karnabahar görüntüsündedir. Prognozu oldukça iyidir. Lateral olarak çevreye doğru yavaş büyümesi ve lenf nodlarına metastaz yapma riskinin düşük olması tümörün prognozunun iyi olduğunu gösterir 1,7,8.

Bazaloid SHK (bazoskuamöz hücreli karsinom) nadir rastlanan ve oral SHK'nın agresif formu olarak kabul edilen ayrı bir histopatolojik tablodur. Özellikle ağız tabanı ve dil yerleşimli ülsere, ekzofitik ve infiltre tümörlerde bu tip düşünülmelidir. Tümör genelde dilin arka kısmını ve ağız tabanını daha fazla etkiler. Yüksek metastaz ve kötü prognoz özelliğine sahiptir9. Oral SHK'nın diğer alt tipleri adenoskuamöz karsinom, papiller SHK, iğsi hücreli karsinom ve akantolitik SHK olarak bilinir 1 .

\section{Tanı}

Erken tanı prognostik açıdan ve cerrahi müdahalenin minimalize edilmesi açısından çok önemlidir. Eğer soliter lezyon 3 haftadan daha uzun süredir devam ediyorsa, bu büyük şüphe uyandırmalıdır ve biyopsi her zaman gereklidir. Genelde eksizyonel biyopsi yapılır ve yüksek mitotik aktiviteli hücrelerin yoğun olduğu lezyon alanlarını saptamak için toluidin mavisi boyası kullanılabilir. Hastalarda tüm ağız mukozası ve servikal lenf nodları muayenesi mutlaka yapılmalıdır. Bunun dışında endoskopi, bilgisayarlı tomografi, manyetik rezonans ve PET taraması hastalığın tanısı, evresi,

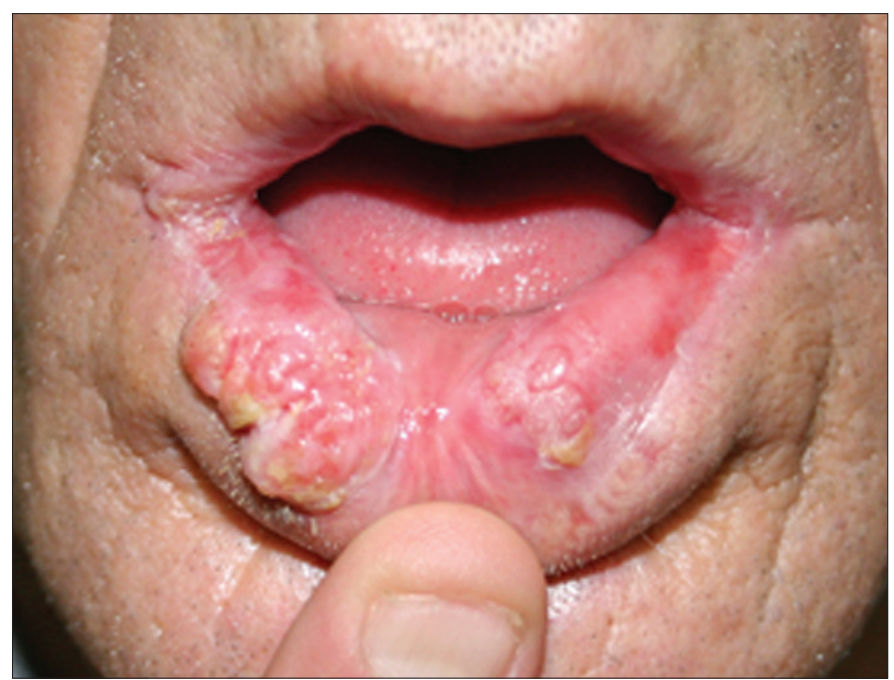

Resim 3. Alt dudakta yüzeyi ülsere infiltre plak 
metastazın varlığı hakkında yardımcı olmaktadır. Oral SHK, tedavi planlamasında çok önemli olan TNM sınıflandırmasına göre evrelendirilir10-12 (Tablo 1).

\section{Tedavi}

Tedavi seçenekleri kanserin evresine, tümörün büyüklüğüne, yerleşim yerine, hastanın yaşına, genel sağılk durumuna göre değişebilir. Standart tedavi yöntemi olarak genelde cerrahi ve radyasyon tedavisi uygulanır. Bazı hastalarda kemoterapi gerekli olabilir3,6,11.

Cerrahi tedavide tümör kitlesinin çevre sağlıklı doku ile birlikte genişletilmiş lokal eksizyonu yapılmalıdır. Boyun lenf nodu tutulumu varsa lenf nodu diseksiyonu yapılabilir. Kemik tutulumunda işlem, kemik eksize edilerek uygulanır. Yapılan cerrahi eksizyon sonrası yüz, ağız boşluğu ve boyun rekonstrüksiyonu için plastik cerrahiye başvurulabilir. Eksternal radyasyon tedavisinde çevre sağlıklı dokuların da ışına maruz kalma riski göz önüne alınarak, doğrudan tümör kitlesinin içine yerleştirilen iğne, teller, kateter gibi internal radyasyon tedavi yöntemleri uygulanabilir. Tümörün evresi, lokalizasyonu, metastaz, vasküler invazyonun varlığı, sigara önemli prognostik faktörlerdir1,12,13

\section{Minör Tükürük Bezi Karsinomları}

Tükürük bezi tümörlerinin yaklaşık \%10-15'ini minör tükürük bezi tümörleri oluşturur. Bunların yaklaşık \%50'si malign özellikler gösterir. Adenoid kistik karsinom, mukoepidermoid karsinom, polimorfik düşük dereceli adenokarsinom bunlardan en sık görülenleridir14.

\section{Adenoid Kistik Karsinom}

Adenoid kistik karsinom tübüler, solid, kribriform şekillere sahip olan bir tümördür. Tüm tükürük bezi tümörlerinin $\% 10^{\prime} u n u$, minör tükürük bezi malign tümörlerinin ise yaklaşık \%30'unu oluştururlar. En sık damakta yerleşim gösterseler de dilde, oral mukozada, ağız tabanında da rastlanabilirler. Klinik olarak en sık görülen semptomu yavaş büyüyen şişlik ve sonrasında perinöral invazyona bağlı gelişen ağrıdır. Fasyal sinir paralizisi bazen tümörün ilk belirtisi olabilir. Bu tümörler yüksek rekürrens

\section{Tablo 1. Oral skuamöz hücreli karsinomun TNM sınfflandırması1,10}

Primer tümör boyutu $(T)$

Tx Tümör değerlendirilemiyor

TO Primer tümör yok

Tis Karsinoma in situ

T1, T2, T3, T4 Tümörün artan boyutu

Bölgesel lenf nodu tutulumu (N)

$\mathrm{Nx} \quad$ Lenf nodları değerlendirilemiyor

NO Lenf nodu metastazı yok

N1 Tek ipsilateral lenf nodu $3 \mathrm{~cm}$ veya $3 \mathrm{~cm}$ 'den küçük

$\mathrm{N2a} \quad$ Tek ipsilateral lenf nodu 3-6 $\mathrm{cm}$ boyutunda

N2b Multipl ipsilateral lenf nodları 6 cm'den küçük

N2c Bilateral veya kontralateral lenf nodu metastazı $6 \mathrm{~cm}$ 'den küçük

N3 ipsilateral, bilateral veya kontralateral lenf nodu metastazı $6 \mathrm{~cm}$ 'den büyük

Uzak metastaz (M)

Mx Uzak metastaz değerlendirilemiyor

M0 Uzak metastaz yok

M1, M2, M3 Uzak metastaz var potansiyeline sahiptir. Ayırıcı tanı içine pleomorfik adenom, polimorfik düşük dereceli adenokarsinom, bazal hücreli adenom, bazaloid skuamöz karsinom alınabilir. Önemli prognostik faktörleri tümörün histolojik paterni, lokalizasyonu, klinik evresi, kemiklere invazyonu, metastazı ve cerrahi sınırlarıdır. Bunlardan en önemlisi klinik evredir. Boyun lenf nodlarına ve akciğerlere metastaz sıklıkla bildirilmiştir. Bu tümörde tedavi yaklaşımı genellikle cerrahi rezeksiyon ve postoperatif radyasyon şeklindedir14,15.

\section{Mukoepidermoid Karsinom}

Mukoepidermoid karsinom çocuk ve erişkinlerde minör tükürük bezlerinin en sık rastlanan primer malign tümörüdür. Genelde damakta yerleşir. Histolojik olarak düşük, orta, yüksek dereceli olarak sınıflandırılır. En sık rastlanan semptomu ağrısız, yavaş büyüyen şişliktir. Düşük dereceli iyi diferansiye hücrelerden oluşmuş, düzgün kenarlı tümörler olup USG ve BT incelemelerinde benign görünümlüdürler. Tümör ortalama $2-5 \mathrm{~cm}$ boyutunda, iyi sınırlı ama enkapsüledir. Yüksek dereceliler az diferansiye hücrelerden gelişen agresif tümörlerdir. Bu tümörlerde nüks oranı yüksek olup, prognoz kötüdür. Tüm mukoepidermoid karsinomlar metastaz yapabilir, ama genelde yüksek dereceli tümörler metastaz yapar. Cerrahi tedavi ve radyasyon tedavisi yapılır16,17.

\section{Polimorfik Düşük Dereceli Adenokarsinom}

Polimorfik düşük dereceli adenokarsinom genelde minör tükürük bezlerinden gelişir, en sık sert damakta rastlansa da üst dudak, yanak mukozasında, dilin posteriorunda, retromolar alanda da görülebilir. Tedavide cerrahi yöntem uygulanır ${ }^{18}$

\section{Oral Lenfomalar}

Ağız boşluğu malign lenfomaları nadir rastlanan malignitelerden olup mastikator mukozada daha sık yerleşirler. Dil ve yanak mukozası nadiren etkilenir1,19. Histolojik tipleri arasında B-hücreli lenfomalara daha sık rastlanır ki, bunlardan da en sık görülen alt tipleri diffüz büyük B-hücreli lenfoma (DBBHL), foliküler lenfoma (FL), kronik lenfositik lösemi ( $K L L)$, küçük hücreli lenfositik lenfoma (KLL), mukozayla ilişkili lenfoid doku (MALT) lenfoması, mantle hücreli lenfoma ( $\mathrm{MHL}$ ) ve Burkitt lenfomadır19,20. Ağız boşluğunda en sık rastlananlar BBHL ve MALT alt tipleridir. HIV infekte hastalarda ve Epstein-Barr Virüs (EBV) infeksiyonunda lenfoma sıklığında (özellikle B lenfoma) artış görüldüğünden, hastaların bu yönden incelenmesi önemlidir20,21.

DBBHL en sık görülen Non-Hodgkin lenfoma tipidir ve en sık lokalize olduğu anatomik bölge Waldeyer halkasıdır. Ayrıca dil üzerinde, gingivada, tükürük bezlerinde de görülebilir. Klinik olarak hızla büyüyen şişlik, ağrı, bazen ülsere lezyon şeklinde kendini gösterebilir. Tonsil tutulumlu lenfomalar daha kötü prognozludur. MALT lenfoma en sık midede görülmesine rağmen akciğer, tükürük bezleri, tiroid, deri, bağırsak ve karaciğerde de rastlanır. Oral MALT lenfoma nadiren görülür. Sjögren hastalığı ve Hashimoto hastalığı gibi otoimmün hastalıklarda görülme sıklığı artar. Non-Hodgkin lenfomaların tedavisi genelde kemoterapi ve radyasyon tedavisi șeklindedir1,22,23.

\section{Bazal Hücreli Karsinom (BHK)}

BHK gelişiminde en önemli tetikleyici faktör güneş ışınlarıdır. Bu nedenle en sık baş ve boyunun güneş gören yerlerinde ortaya çıkar24. Genelde \%95'i 40 yaşından sonra gelişir. Diğer anlamlı risk faktörleri; yanıklar, aşılar, 
ışınlar, arsenik, kseroderma pigmentozum, Gorlin sendromu, albinizm ve Bazex sendromu şeklinde sıralanır. Dudakta genelde incimsi, bazen ülsere nodül ve papül şeklinde kendini gösterir. SHK'dan farklı olarak vermillon sınırından nadiren gelişir, perioral yerleşim sık rastlanır (Resim 4).

Nodüler BHK, dudak çevresindeki yarı saydam nodül, telenjiyektazili ve ülsere lezyonlarla karakterizedir. Morfeik BHK sikatrise benzer atrofik plak, agresif infiltre büyüme paterni ve eksizyon sonrasında yüksek sıklıklı rekürrens ile karakterizedir. Yüzeyel BHK ise çevreden kabarık, merkezi atrofi veya ülserasyon gösteren eritematöz plak lezyonları şeklindedir. Dudak kenarında az rastlanır ve nadiren metastaz yapar1. Oral BHK'un ayrıcı tanısı skuamöz hücreli karsinom, keratoakantom, trikoepitelyoma ve sebase adenom ile yapılır. Tedavisinde cerrahi eksizyon, elektrokoterizasyon, kriyoterapi, küretaj, lazer cerrahisi, radyasyon tedavisi, intralezyonel kemoterapi veya interferon A uygulanır. Bazı olgularda nadir de olsa kendiliğinden gerileme olabilir1,24,25.

\section{Kaposi Sarkomu}

Oral Kaposi sarkomuna çoğunlukla HIV ile infekte kişilerde, başlıca homoseksüel erkeklerde rastlanır. HIV ile ilişkili Kaposi sarkomu (HIV-KS) infeksiyonun pandemik olduğu ve anti-retroviral ilaçların yetersiz olduğu Afrika ülkelerinde daha yaygındır26.

HHV-8 virüsü Kaposi sarkomunun önemli nedenlerinden olup, ancak tek etyolojik neden değildir. Afrika'da endemik olan infeksiyon, HIVseronegatif kişilere kıyasla HIV-seropozitiflerde önemli ölçüde daha yaygındır. Erkek homoseksüel kişilerin \%50'sinde oral Kaposi sarkomu gelişir ve \%20-60 sıklıkta oral kandidiyazis ile beraber olabilir . Oral Kaposi sarkomu ayrıca HIV infeksiyonu olmayan immunyetmezliği olan hastalarda görülür.

Klasik, endemik, iatrojenik ve epidemik şeklinde dört klinik çeşidi mevcuttur. Klinik seyri klasik şeklinde görülen zararsız lezyonlardan, epidemik şeklinde görülen hızlı seyirli ve ölümcül lezyonlara kadar değişebilir. Kaposi sarkomu sıklıkla sert damağı etkiler (Resim 5). Bunun yanı sıra yumuşak damakta, daha az sıklıkta gingivada, dil ve yanak mukozasında görülür. Kırmızı-morumsu renkte makül başlangıç lezyonu olup, zamanla morumsu nodüller gelişir ve ülserasyonlar oluşabilir. Genelde birden fazla olan lezyonlar asemptomatik seyreder26. Bazen ağıılı, kanamalı olabilirler.

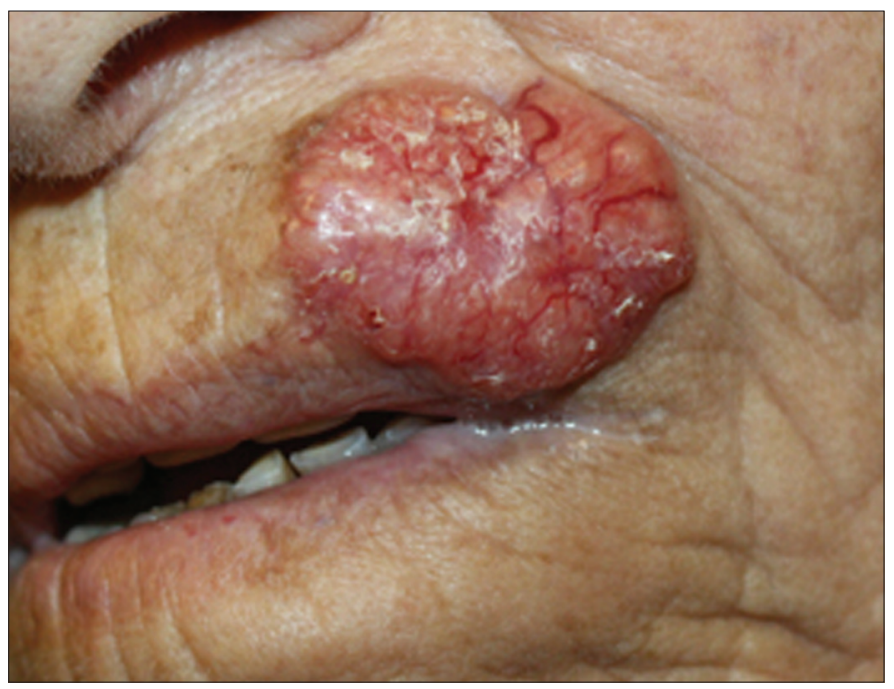

Resim 4. Perioral yerleşimli nodüler bazal hücreli karsinom
Kaposi sarkomunda tedavinin amacı tümörü küçültmek, semptomların şiddetini azaltmak ve hastalığın ilerlemesini önlemektir27. Oral yerleşimli Kaposi sarkomu kendiliğinden gerileyebilir. Tedavisinde yüksek aktiviteli anti-retroviral tedavi, cerrahi eksizyon, zidovudin veya sistemik vinka alkaloidleri, etiposid, interferon tedavisi uygulanabilir. En etkili tedavi tedavi lokal radyasyon tedavisidir. Bir kısım olgularda intralezyonel vinblastin de faydalıdır28,29

\section{Melanom}

Oral melanom nadir rastlanan tümörlerden olup çoğu hasta 50 yaşın üzerindedir ve erkeklerde daha sıktır. Melanom normal oral mukoza veya mevcut pigmente nevüsden, sıklıkla damak ve maksiller alveollerde gelişirir 1,30 .

Başlangıç semptomu ve bulgusu pigmente büyüme veya şişliktir. Lezyon üzerindeki mukoza sağlam veya ülseredir. Primer tümörün çevresinde satellit odaklar olabilir. Melanomun rengi düzgün kahverengi, siyah veya kahverengi, gri, mor ve kırmızı tonların karışımı şeklinde görülebilir. Metastatik melanom nadirdir. Hızı büyüme, renk değişimi, ülserleşme, ağrı, kanama, satellit pigmente noktalar, lenf nodu büyümesi gibi özellikleri malignite yönünde düşündürür.

Klinik olarak oral melanomlar beş tipe ayrılır: pigmente nodüler, nonpigmente nodüler, maküler, karışık pigmentli ve karışık non-pigmente melanom31. Akciğer, beyin, karaciğer ve kemiklere metastaz sıklıkla görülmektedir. Histolojik kesitlerde anaplastik iğsi veya skuamoid hücreler görülebilir. Çoğu olguda S-100, tirozinaz ve MART-1/melan-A ile pozitif boyanma tanıya yardımcıdır31-33.

En ideal biyopsi tekniği lezyonun 1-2 mm'lik sağlam sınıla eksizyonel biyopsisidir. Tedavisi tartışmalıdır. Tümör kitlesinin sağlıklı dokunun en az $1,5 \mathrm{~cm}$ içine alınmasıyla eksizyonu önerilir. Oral melanom olgularının \%25-30'unda lenf nodu metastazı görülür. Bu olgularda boyun diseksiyonu yapılabilir. Cerrahi tedavi radyasyon tedavisi ve/veya

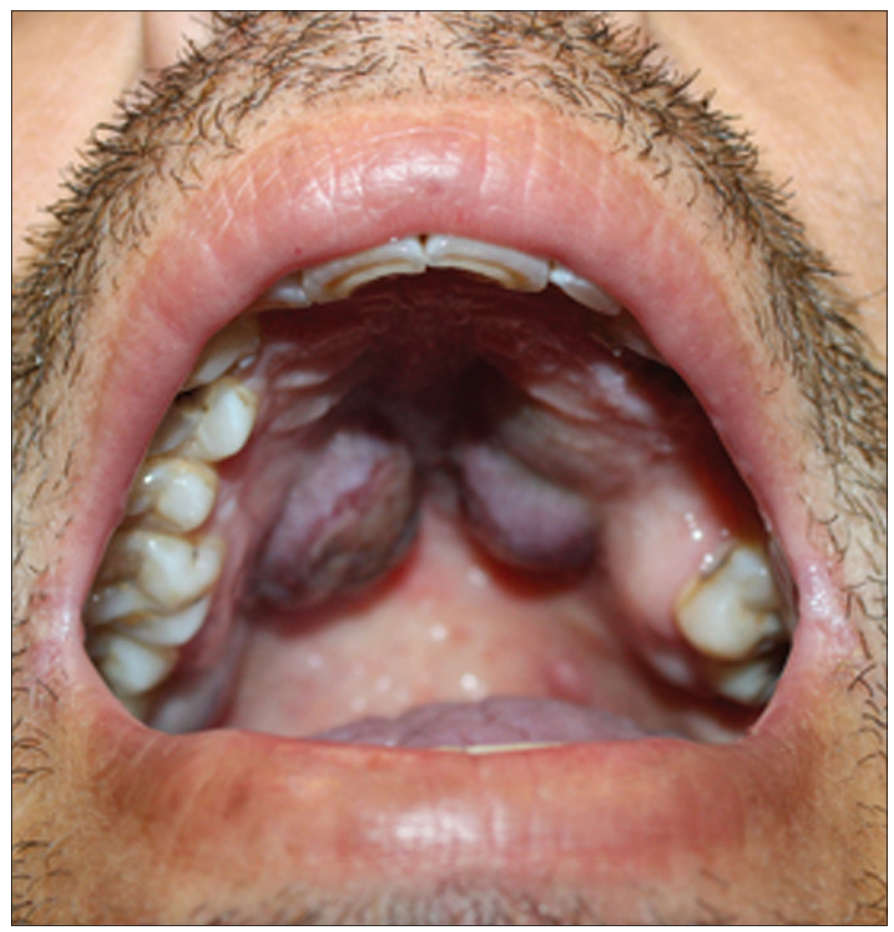

Resim 5. Damak yerleşimli morumsu nodüller 
kemoterapi ile kombine edilebilir. Oral melanomlar yeterince radyosensitif kabul edilmeseler de, birden fazla pozitif nodül veya metastatik melanomun ekstranodal yayılması durumunda postoperatif radyasyon tedavisi tavsiye edilir. Dakarbazin, platin analogları, nitrozüreler, mikrotübüler toksinler, vinkristin, hidroklorür adjuvan tedavi veya postoperatif kemoterapi olarak uygulanabilir1,32,33. Tümörün kalınlığının 5 mm'den fazla olması, vasküler invazyon, nekroz, polimorf tümör hücre morfolojisi kötü prognoza işarettir32.

\section{Metastatik Oral Tümörler}

Metastatik oral tümörler tüm oral tümörlerin \%1'ini içermekte olup en sık mandibulada ülser ve gingival şişlikle kendini gösterir. Meme, böbrek, akciğer, tiroid, mide, karaciğer, barsak ve prostat kanseri ağız içi metastaz yapabilir. Hematojen ve lenfojen yolla yayılır. Tedavisi semptomatiktir. Cerrahi, radyasyon tedavisi veya kemoterapi yapılabilir31.

\section{Kaynaklar}

1. Scully C, Hegarty A: The oral cavity and lips. Rook's Textbook of Dermatology. Eds. Burns T, Breathnach S, Cox N, Griffiths C. 8. Baskı. Massachusetts, Blackwell Publishing, 2010; 69.1- 69.129.

2. Podlodowska J, Szumiło J, Podlodowski W, Starosławska E, Burdan F: Epidemiology and risk factors of the oral carcinoma. Pol Merkur Lekarski 2012;32:135-7.

3. Koduganti RR, Sehrawat S, Reddy PV: Gingival squamous cell carcinoma: A diagnostic impediment. J Indian Soc Periodontol 2012;16:104-7.

4. Haas SL, Ye W, Löhr JM: Alcohol consumption and digestive tract cancer. Curr Opin Clin Nutr Metab Care 2012;15:457-67.

5. McLemore MS, Haigentz M Jr, Smith RV, et al: Head and neck squamous cell carcinomas in HIV-positive patients: a preliminary investigation of viral associations. Head Neck Pathol 2010;4:97-105.

6. Smee RI, Broadley K, Bridger GP, Williams J: Floor of mouth carcinoma: surgery still the dominant mode of treatment. J Med Imaging Radiat Oncol 2012;56:338-46. doi: 10.1111/j.1754-9485.2012.02387.x.

7. Morris LGT, Patel SG, Shah JP, Ganly I: Squamous Cell Carcinoma of the Oral Tongue in the Pediatric Age Group. Arch Otolaryngol Head Neck Surg 2010;136:697-701

8. Tettamanti L, Caprioglio A, Tecco S, et al: Oral Squamous Cell Carcinoma in the patient: a literature review. Eur J Paediatr Dent 2012;13:35-40.

9. Rachel JR, Kumar NS, Jain NK: Basaloid squamous cell carcinoma of retromolar trigone: A case report with review of literature. J Oral Maxillofac Pathol 2011;15:192-6.

10. Lindenblatt Rde C, Martinez GL, Silva LE, et al: Oral squamous cell carcinoma grading systems-analysis of the best survival predictor. J Oral Pathol Med 2012:41:34-9. doi: 10.1111/j.1600-0714.2011.01068.x.

11. Soudry E, Preis M, Hod R, et al: Squamous cell carcinoma of the oral tongue in patients over 75 years old. Aging Clin Exp Res 2011;23:231-5.

12. Melchers LJ, Schuuring E, van Dijk BA, de Bock GH, et al: Tumour infiltration depth $\geq 4 \mathrm{~mm}$ is an indication for an elective neck dissection in PT1cNO oral squamous cell carcinoma. Oral Oncol 2012;48:337-42.
13. Sun J, Gao Q, Fan VT: Multifocal cutaneous metastases from squamous cell carcinoma of hard palate. Int J Oral Maxillofac Surg 2012;41:807-9.

14. Fujita S, Ikeda T: Cancer stem-like cells in adenoid cystic carcinoma of salivary glands: relationship with morphogenesis of histological variants. J Oral Pathol Med 2012;41:207-13. doi: 10.1111/j.1600-0714.2011.01096.x.

15. Shen C, Xu T, Huang C, Hu C, He S: Treatment outcomes and prognostic features in adenoid cystic carcinoma originated from the head and neck. Oral Oncol 2012;48:445-9.

16. Sobani ZU, Junaid M, Ghaffar S, Suhail A: Mucoepidermoid carcinoma of the base of tongue. J Pak Med Assoc 2011;61:945-7.

17. Kakarala K, Bhattacharyya N: Survival in oral cavity minor salivary gland carcinoma. Otolaryngol Head Neck Surg 2010;143:122-6.

18. Abu El-Naaj I, Leiser Y, Wolff A, Peled M: Polymorphous low grade adenocarcinoma: case series and review of surgical management. J Oral Maxillofac Surg 2011;69:1967-72.

19. Müller AM, Ihorst G, Mertelsmann R, Engelhardt M: Epidemiology of nonHodgkin's lymphoma (NHL): trends, geographic distribution, and etiology. Ann Hematol 2005:84:1-12.

20. Tanaka T, Kitabatake K, lino M, Goto K: Tetraploidy with double t $(11 ; 18)$ of recurrent MALT lymphoma in buccal mucosa: a case report. Oral Surg Oral Med Oral Pathol Oral Radiol 2012;113:399-403. doi: 10.1016/j.0000.2011.08.011.

21. Kato $H$, Kanematsu $M$, Goto $H$, et el: Mucosa-associated lymphoid tissue lymphoma of the salivary glands: MR imaging findings including diffusionweighted imaging. Eur J Radiol 2012;81:612-7.

22. Manveen JK, Subramanyam R, Harshaminder G, Madhu S, Narula R: Primary B-cell MALT lymphoma of the palate: A case report and distinction from benign lymphoid hyperplasia (pseudolymphoma). J Oral Maxillofac Pathol 2012;16:97-102.

23. Gill H, Chim CS, Au WY, Loong F, Tse E, Leung AY, Kwong YL: Non-gastric marginal zone B cell lymphoma: clinicopathologic features and treatment results. Ann Hematol 2011:90:1399-407.

24. Czerninski R, Zini A, Sgan-Cohen HD: Lip cancer: incidence, trends, histology and survival: 1970-2006. Br J Dermatol 2010;162:1103-9.

25. Mlika RB, Kerkeni $N$, Jebali $A$, et al: Basal cell carcinoma of unusual site. Ann Pathol 2011;31:32-5.

26. Zaraa I, Labbene I, El Guellali N, et al: Kaposi's sarcoma: epidemiological, clinical, anatomopathological and therapeutic features in 75 patients. Tunis Med 2012;90:116-21

27. Fatahzadeh M: Kaposi sarcoma: review and medical management update. Oral Surg Oral Med Oral Pathol Oral Radiol 2012;113:2-16 doi: 10.1016/j.tripleo.2011.05.011.

28. Cheng R, Patel S, Mandel L: Oral manifestations in untreated HIV patient. N Y State Dent J 2011:77:58-60.

29. Mosam A, Shaik F, Uldrick TS, et al: A randomized controlled trial of highly active antiretroviral therapy versus highly active antiretroviral therapy and chemotherapy in therapy-naive patients with HIV-associated Kaposi sarcoma in South Africa. J Acquir Immune Defic Syndr 2012;60:150-7.

30. Morita SY, Markovic SN: Molecular targets in melanoma: time for 'ethnic personalization'. Expert Rev Anticancer Ther 2012;12:601-8.

31. Hajar-Serviansky T, Gutierrez-Mendoza D, Galvan IL, et al: A case of oral mucosal melanoma. Clinical and dermoscopic correlation. J Dermatol Case Rep 2012;6:1-4.

32. Meleti M, Leemans $C R$, Mooi WJ, Vescovi $P$, van der Waal I: Oral malignant melanoma: a review of the literature. Oral Oncol 2007;43:116-21.

33. Medina JE, Ferlito A, Pellitteri PK, et al: Current management of mucosal melanoma of the head and neck. J Surg Oncol 2003;83:116-22. 


\section{Hatırlama soruları}

1. Hangi HPV tipi oral skuamöz hücreli kanser gelişimi için en risklidir?
a. 16
b. 18
c. 30
d. 32
e. 36

Cevap: a

2. Hangisi en iyi prognozlu skuamöz hücreli karsinom tipidir?
a. Bazaloid
b. Ackerman tümörü
c. Adenoskumaöz
d. İğsi hücreli
e. Papiller

Cevap: $b$

3. Hangisi oral melanom tipi değildir?
a. Pigmente nodüler
b. Non-pigmente nodüler
c. Karışık pigmentli
d. Maküler
e. Süperfisyel

Cevap: e 